\title{
The Nigerian State and the Proliferation Small Arm and Light Weapons in the Northern Part of Nigeria
}

\author{
Barrister. Okeke, V.O.S. PhD \\ Department Of Political Science, Faculty Of Social Sciences \\ Anambra State University, Igbariam, Anambra State, Nigeria \\ E-mail: okekevos@yahoo.com \\ Oji, R. O. PhD \\ Department Of Political Science, Faculty Of Social Sciences \\ Enugu State University Of Science And Technology, Enugu, Nigeria \\ E-mail: drokeyoj@yahoo.com
}

\section{Doi:10.5901/jesr.2014.v4n1p415}

\begin{abstract}
The changing trend of national and international threats to national security is occasioned by the evolution and development of new factors in the internal and external environment of the Nigerian state. The security of the Nigerian state is aimed at protecting the national integrity of the state and defending the essential values that constitute Nigerian identity. Nigeria is rated high in the regional debate for the control of small arms and light weapons and illegal trade. For more than a decade, diplomatic activity to contain arms and ammunition transfers has been animated by a concern with instability and crises generated in the continent many years back. Leading think tanks, research groups, and advocacy organizations have repeatedly drawn attention to the way the burden of armed violence in Northern Nigeria is a product of high porous borders and low-tech assault by the Nigerian government. The methodology was based on the use of secondary data. The secondary data were collected from textbooks, journals, magazines, periodicals, internet, etc. We started by dwelling on the entire technicality where we posed four research questions, stated four specific objectives, and four research hypotheses. We, also, demonstrated the theoretical and empirical relevance or justifications of this study. We also reviewed the related extent and relevant literature concerning causes, sources, transits and destinations of SALW and problems and consequences of SALW in Nigeria. We further discussed the history of proliferation of SALW in Nigeria, and the Nigerian state and proliferation of SALW in the Northern Nigeria. Whilst, we examined the supply factors and causes of proliferation of SALW, and the law enforcement agencies, SALW proliferation and security situations in the Northern Nigeria. Lastly, effort was made to summarize the entire work and drew some conclusions on the basis of which we made some recommendations. From the foregoing, we reached the following conclusions that: the inability of the Nigerian state to deal with the demand factors heightened the proliferation of SALW in the Northern part of Nigeria. The inability of the law enforcement agencies to check the supply factors of SALW worsened security situations in the Northern part of Nigeria. Reconstitute the Nigerian state in such a way as to be pro-active in dealing with the demand factors of SALW that heightens the proliferation of SALW. Strengthen the law enforcement agencies in order to enable them check the supply factors of SALW that worsens security situations in the Northern part of Nigeria. Thus the thrust of this paper is to look at the Nigerian state and the proliferation small arm and light weapons in the northern part of Nigeria.
\end{abstract}

Keywords: Nigerian State, Proliferation, Small Arm and Light Weapons, Northern Nigeria

\section{Introduction}

Nigeria is highly diverse, pluralistic and heterogeneous or multiethnic and multi-religions with over two hundred ethnolinguistic groups and two major religious groups. Thus, sequel to the amalgamation of the Northern and the Southern protectorates in 1914, the mistake of 1914 so called, two major issues are said to be dividing Nigeria, namely, ethnicity and religions, that one often wonders which of them divides Nigeria more. These two divisive elements in the contemporary Nigeria result to numerous ethno-religious violence in the Northern part of Nigeria (Aniche, 2006). The colonial authority created these diversities but made little effort to unite the country rather deepened division of the country through divide and rule aimed at frustrating any concerted or united resistance against it in order to perpetually suppress the people. At the independence, the political leadership and indeed the political class further deepened these 
divisions created by colonial rule by raising ethno-religious consciousness at the expense of class consciousness on their intense power struggles and political contests for the control of the Nigerian state (Okafor, Okeke and Aniche, 2012). Thus, the process of state formation and nation-building are at the incipient stage. Therefore, ethno-religious conflicts seem to be a part of the unfinished business of state formation and nation building. All these constitute part of the demand factors for proliferation of small arms and light weapons (SALW) in Nigeria. The point is that the proliferation of SALW in Nigeria is a product of failure of political leadership due to bad leadership, poor governance, militarization of the society and state violence leading to poverty, mass unemployment, economic crisis of development and other forms of poor human development indices in Nigeria (John, Mohammed, Pinto and Nkanta 2007). Nigeria is a source/origin, transit and destination of SALW. The causes of the proliferation of SALW is well documented in the literature, for examples, crime, revolts, subversion, sabotage, religious crisis, communal conflicts, social agitations, micro-nationalism, insurrection, terrorism, insurgency, riots, militancy, electoral violence, political violence, social interest, ethnic tensions, cross border smuggling, porous borders, black marketeering, local manufacturing, privatization of security, insecurity, poverty, economic crisis, mass unemployment, among others. Some of the scholars focus on the supply side or push factors of proliferation of SALW like willing sellers, lucrativeness, and porous borders while others concentrate on demand or pull factors like crime, violence, conflicts, riots and unrests (Ayissi and Sall (eds), 2005; Florquin and Berman (eds), 2005; Vines, 2005; Hazen and Horner (eds), 2007; Stohl and Tuttle 2009; Chuma-Okoro, 2011; Nte, 2011).

\subsection{Statement of the Problem}

Statement of problem is the fundamental question that requires an answer, it is the most worrying issues that need to be properly examine and understood. It is a fundamental question because many other specific research questions are derived from it. The research problem is the fulcrum which the research objective and hypotheses revolve (Obasi, 1999). Under the statement of problem the researcher is expected to examine the 'why' related issues the researchers does not only describe as such but rather raise question that attract curiosity and expectation in terms of answer. Nigeria is a diverse and a vast country covering 923, 768 square kilometers with more than 36, 450 kilometers of land and maritime borders, and shares land borders with four countries namely, Benin Republic in the West, Chad and Niger in the North, and Cameroon in the East. It shares international water Lake Chad in the North with Niger, Chad and Cameroon, and a maritime border coastline in the Gulf of Guinea or Atlantic Ocean. Along the Western border, Nigeria has 770 kilometers of shared land border with the Republic of Benin, in the North, around 1,500 kilometers with Niger and 90 kilometers with Chad and in the West, 1,700 kilometers with Cameroon. Along the Southern coastline it also shares 853 kilometers of maritime border with the Atlantic Ocean known as the Gulf of Guinea. All totaling an outstretch of about $4910 \mathrm{~km}$ of borders (Yacubu, 2005; Stohl and Tuttle, 2009; Nte, 2011). Despite the effort of cross-border security agencies like the Nigeria police, customs service, Immigration services, etc, Nigeria borders have been described as porous allowing illicit arms trafficking resulting to proliferation of SALW. Nigeria is a source/origin, transit and destination of illicit and illegal arms trafficking. Therefore, the source of proliferation of SALW is a well linked to local manufacturing. Even the legal acquisition of SALW for various security agencies by the Nigerian government eventually illegally finds their way to militia groups (Yacubu, 2005; Adejo, 2009; Nte, 2011). Not surprisingly, out of the 640 million small arms circulating globally, it is estimated that 100 million are found in Africa about 30 million in sub-Saharan Africa and 8 million in West Africa, alone. The majority of these SALW about $59 \%$ are in the hands of civilians, $38 \%$ are owned by government armed forces, $2.8 \%$ by police and $0.2 \%$ by armed groups. The gun trade is worth $\$ 4$ billion annually, of which up to $\$ 1$ billion may be unauthorized or illicit. Eight million new guns are manufactured every year by at least 1, 249 companies in 92 countries. Ten to 14 billion units of ammunition are manufactured every year enough to kill every person in the world twice over. African countries spent over 300 billion dollars on armed conflict between 1990 and 2005 equaling the sum of international aid that was granted to Africa within the same period. An estimated $79 \%$ of small arms in Africa are in the hands of civilians (Ibrahim, 2003; Stohl and Tuttle, 2009; Nte, 2011). Between 1999 and 2003, there were over 30 communal clashes, sectarian violence and ethno-religious conflicts with each claiming hundreds of lives and properties, and internal displacement of women and children. The proliferation and use of SALW in ethno-religious clashes and armed robbery have killed more than 10,000 Nigerians, an average of 1000 people per year since 1999. The majority of casualties about $66 \%$ in Kano riot of 2004 were SALW victims sustaining permanent disabilities. Injuries due to SALW have increased as much as ten-fold in urban Nigeria because most homicides are committed using SALW (John, Mohammed, Pinto and Nkanta, 2007; Nte, 2011). The problems of armed violence and proliferation of SALW are worsened by the inability of the police to reduce violent crime, ensure law and order and provide adequate security to the populace. None of the security agent currently possesses the training, resources or personnel to perform their duties 
effectively due to lengthy and porous nature of Nigerian borders (Hazen and Horner, 2007). Nte (2011) posits that there is a direct link between the acquisition of weapons like SALW and escalation conflicts into a full-brown war. Yet none of these scholars have been able to address the fundamental issues and root causes of proliferation of SALW and ethnoreligious violence in Nigeria. The role of the Nigerian state and its law enforcement agencies in orchestrating these, with the demand or pull factors as well as checking the supply or push factors have not been given adequate systematic inquiry in the literature and this is the point of our departure. This is the point from where we depart.

\subsection{Research Questions}

Research question is the fundamental question about the study that requires an answer. It is the fundamental question because other specific research questions derive from it. It, also, shapes or determines the research objectives and hypotheses. Obasi (1999) notes that research question is the most worrying issue or fact that needs to be properly examined and understood.From the foregoing, therefore, we raised the following questions:

Has the inability of the Nigerian state to deal with the demand factors heightened the proliferation of SALW in the Northern part of Nigeria?

Has the inability of the law enforcement agencies to check the supply factors of SALW worsened security situations in the Northern part of Nigeria?

\subsection{Objectives of the Study}

Under the objectives of the research, one is required to state in concrete terms, what are expected to be achieved at the end of the research. In other words, it represents the end product of what is being researched upon, in terms of the expectation or solution required. One is therefore required to present identifiable or concrete things to be accomplished by the research. This study has broad and specific objectives. The broad or general objective is to examine the role of policy makers, defense and national security advisers in checking SALW in the Northern Nigeria. While the specific objectives include the following:

To ascertain if the inability of the Nigerian state to deal with the demand factors heightened the proliferation of SALW in the Northern part of Nigeria.

To ascertain whether the inability of the law enforcement agencies to check the supply factors of SALW worsened security situations in the Northern part of Nigeria.

\subsection{Significance of the Study}

The significance of the study is, one, the value or contribution which the research is going to make to existing knowledge in terms of theoretical justification or relevance; and two, the solution the research is going to provide towards ameliorating a practical problem of concern (Obasi, 1999). A research can be justified because it is (i) timely, topical or auspicious (ii) closing an existing gap in knowledge or the literature (iii) theoretically relevant (iv) practically relevant (v) in accordance with national priority (vi) in accordance with priorities set by research funding agency (vii) wider in scope in terms of issues covered or geographical arrears covered, and (viii) useful for confirming/accepting or rejecting existing findings. It lists out the groups, institutions that are likely to benefit from the findings or discoveries of research. Therefore, the study has theoretical and practical relevance. The theoretical relevance of this study is that it examines the role of policy makers, defence and national security advisers in checking SALW in the Northern Nigeria.

By so doing, the study enriches the existing stock of literature or expands the frontiers of knowledge through its findings, therefore serves as a source of data/material to those scholars who may be interested in further studies in this area.

Empirically or practically, this study will be of immense benefits to government, security advisers, defence advisers, policy makers, politicians, regional institutions like AU, ECOWAS, etc, international institutions like UN, WB, etc. the study is timely, because the process is ongoing.

\subsection{Hypotheses}

A hypothesis is simply a tentative statement which is open to confirmation or rejection when exposed to empirical verification. It is defined by Lundberg (1951) as "a tentative generalization whose validity remains to be tested". 
Simplifying further, Lundberg described it as an unsubstantiated generalization. In more technical senses, Abcarian and Masannant (1970:28) define hypothesis as "a proposition that may be confirmed or refuted by new scientific work". In the course of this study, we formulate the following hypotheses:

- That the inability of the Nigerian state to deal with the demand factors heightened the proliferation of SALW in the Northern part of Nigeria.

- That the inability of the law enforcement agencies to check the supply factors of SALW worsened security situations in the Northern part of Nigeria.

\section{Literature Review}

The literature review focuses on identifying contributions already made on the subject matter under investigation. According to Obasi (1999) a review of literature offers an opportunity to identify gaps in existing literature and through identification of such limitations new research problem worth investigating can be discovered. Literature review can be narrow/restricted or comprehensive/broad. There are two major styles or approaches that can be used in organizing a review which are thematic style or chronological style. In this study, we adopted comprehensive or broad literature review and thematic style of review. As such, we use subheading to discuss or review related issues or ideas such as variables that are being studied or hypotheses being investigated. Tuckman (1972) rightly observes that the purpose of the literature review is to expand upon the context and background of the study, to help further define the problem, and to provide an empirical basis for the subsequent development of hypotheses.

\subsection{Review of the Related Literature}

In reviewing the related literature, we discuss the views or contributions of scholars concerning causes, sources, transits and destinations of SALW and problems and consequences of SALW in Nigeria.

\subsection{Causes, Sources, Transits and Destinations of SALW}

Nigeria is a source/origin, transit and destination of SALW. The causes of the proliferation of SALW is well documented in the literature, for examples, crime, revolts, subversion, sabotage, religious crisis, communal conflicts, social agitations, micro-nationalism, insurrection, terrorism, insurgency, riots, militancy, electoral violence, political violence, social interest, ethnic tensions, cross border smuggling, porous borders, black marketeering, local manufacturing, privatization of security, insecurity, poverty, economic crisis, mass unemployment, among others. Some of the scholars focus on the supply side or push factors of proliferation of SALW like willing sellers, lucrativeness, and porous borders while others concentrate on demand or pull factors like crime, violence, conflicts, riots and unrests (Ayissi and Sall (eds), 2005; Florquin and Berman (eds), 2005; Vines, 2005; Hazen and Horner (eds), 2007; Stohl and Tuttle 2009; Chuma-Okoro, 2011; Nte, 2011). Out of the 640 million small arms circulating globally, it is estimated that 100 million are found in Africa about 30 million in sub-Saharan Africa and 8 million in West Africa, alone. The majority of these SALW about 59\% are in the hands of civilians, $38 \%$ are owned by government armed forces, $2.8 \%$ by police and $0.2 \%$ by armed groups. The gun trade is worth $\$ 4$ billion annually, of which up to $\$ 1$ billion may be unauthorized or illicit. Eight million new guns are manufactured every year by at least 1, 249 companies in 92 countries. Ten to 14 billion units of ammunition are manufactured every year enough to kill every person in the world twice over. African countries spent over 300 billion dollars on armed conflict between 1990 and 2005 equaling the sum of international aid that was granted to Africa within the same period. An estimated $79 \%$ of small arms in Africa are in the hands of civilians (Ibrahim, 2003; Stohl and Tuttle, 2009; Nte, 2011). Between 1999 and 2003, there were over 30 communal clashes, sectarian violence and ethnoreligious conflicts with each claiming hundreds of lives and properties, and internal displacement of women and children. The proliferation and use of SALW in ethno-religious clashes and armed robbery have killed more than 10,000 Nigerians, an average of 1000 people per year since 1999. The majority of casualties about $66 \%$ in Kano riot of 2004 were SALW victims sustaining permanent disabilities. Injuries due to SALW have increased as much as ten-fold in urban Nigeria because most homicides are committed using SALW (John, Mohammed, Pinto and Nkanta, 2007; Nte, 2011). The problems of armed violence and proliferation of SALW are worsened by the inability of the police to reduce violent crime, ensure law and order and provide adequate security to the populace. None of the security agent currently possesses the training, resources or personnel to perform their duties effectively due to lengthy and porous nature of Nigerian borders (Hazen and Horner, 2007). Nte (2011) posits that there is a direct link between the acquisition of weapons like SALW and 
escalation conflicts into a full-brown war.

\subsection{Problems and Consequences of SALW in Nigeria}

The proliferation of small arms and light weapons is often one of the major security challenges currently facing Nigeria, Africa and indeed the world in general. The trafficking and wide availability of these weapons fuel communal conflict, political instability and pose a threat, not only to security, but also to sustainable development. The widespread proliferation of small arms is contributing to alarming levels of armed crime, and militancy (Nte, 2011). The first small arms came into general use at the end of the 14th century. Initially they were nothing more than small cannon held in the hands, fired by placing a lighted match at the touch hole. Later a stock was added- the match lock and the first real handgun. Small arms are defined as smaller infantry weapons, such as fire arms that an individual soldier can carry. It is usually limited to revolvers, pistols, submachine guns, shotguns, carbines, assault rifles, rifle squad automatic weapons, light machine guns, general-purpose machine-gun, medium machine guns and hand grenades. However, it can also include heavy machine-guns, as well as smaller mortars, recoilless rifles and some rocket launchers, depending on the context. Large mortars, howitzers, cannons, vehicles and larger pieces of equipment are not considered small arms (Nte, 2011). African countries have experienced direct, indirect and consequential impacts of weapons proliferation. Thousands of people, - both civilians and combatants - are killed or injured every year on the continent. Yet, even when death or injury is avoided, small arms proliferation and misuse can dramatically impact a community, country or region's landscape. The threat and use of small arms can undermine development, prevent the delivery of humanitarian and economic aid, and contribute to refugee and internally displaced persons (IDP) populations (Stohl and Tuttle, 2009). West Africa's regional superpower, Nigeria, continues to face serious challenges. Efforts at reform continue in 2005 but progress is slow and battle lines are already being drawn for the 2007 electoral contest to succeed President Obasanjo. Inter-communal violence remains a serious concern. Since the end of military rule in 1999, fighting in several regions of the country has claimed thousands of lives. Plateau State in central Nigeria has been particularly badly affected (Vines, 2005). A long history of the militarization of society has contributed to the problem of SALW in Nigeria. The military has ruled for the majority of the period following independence from Britain in 1960. During the Biafran Civil War (19671970), large numbers of SALW passed into general circulation. Civil-military relations have worsened since the transition to civilian rule in 1999, and most of the population see the armed forces and police as coercive and corrupt (John, Mohammed, Pinto, and Nkanta, 2007). SALW has been defined in different international and regional instruments, and also in national statutes. A common observation emerging from the different definitions is that the term "small arms and light weapons" covers a wide spectrum of weapons, their ammunitions and their spare parts. The ECOWAS Convention on Small Arms and Light Weapons, their Ammunition and other Related Materials of 2006, which is the West African subregional benchmark for regulating SALW defines small arms as arms destined for personal use and which include: firearms and other destructive arms or devices such as an exploding bomb, an incendiary bomb or a gas bomb, a grenade, a rocket launcher, a missile, a missile system or a mine. Revolvers and pistols with automatic loading, rifles and carbines, machine guns, assault rifles, light machine guns are also examples of SALW (Chuma-Okoro, 2011). Light weapons are the following portable arms designed to be used by several people working together in a team like heavy machine guns, portable grenade launchers, mobile or mounted, portable anti-aircraft cannons, portable antitank cannons, non-recoil guns, portable anti-tank missile launchers or rocket launchers, portable anti-aircraft missile launchers, mortars with a calibre of less than 100 millimetres (Chuma-Okoro, 2011).

\subsection{Theoretical Framework}

Most research is founded on a question that borders on a specific subject matter. The researcher or writer of the report not only questions, but ponders and develops thoughts or theories on what the possible answers could be. These thoughts and theories are then grouped together into themes that frame the subject. This is what is known as a theoretical framework. It's a process of identifying a core set of connectors within a topic and showing how they fit together or are related in some way to the subject in question. Obasi (1999) states that, by theoretical framework, we mean a device or scheme for adopting or applying the assumptions, postulations and principles of a theory in the description and analysis of a research problem. A theoretical framework is used by scientists when preforming research studies to formulate a theory. Theoretical framework is what the scientists have brainstormed about a subject and want the study to answer.It is a way of describing, analysis, interpreting and predicting phenomena. This study is anchored on the combination of the theory of relative autonomy of the state and failed state theory. The state relative autonomy theory 
is situated within the ambit of the neo-Marxist political economy paradigm. The theory of relative state autonomy depicts the level or degree of detachment or aloofness of the state in the discharge of its duties such as mediating inter-class and intra-class struggles. Thus, this theory presupposes that in any state or political society, there are two levels of contradiction, namely primary contradiction and secondary contradiction. Primary contradiction is inter-class struggle or depicts class struggle between two antagonistic classes such as the ruling class and the ruled class or the bourgeois class and the proletariat (i.e. the working class). Whilst, secondary contradiction is the intra-class struggle, denoting class conflicts within the ruling-class or between different segments of the ruling-class. Marx and Engels demonstrate this intractable phenomenon of class struggle when they declare in the preface of their book, The Communist Manifesto that "the history of all the hitherto existing society is the history of class struggles" (Marx and Engels, 1977). The exponents of the theory hold that a state can exhibit either low or high relative autonomy. A state exhibits high autonomy when there is high commodification of capital or excessive penetration of capital into the economy such that the bourgeois class indulges in accumulation of capital through direct exploitation of the working class or appropriation of surplus value when they enter into social relationships of production (i.e. private capitalism). Here, the state is not interventionist, in other words, it does not intervene in the domestic economy like participating in the productive activities (i.e. public/state enterprises) or controlling or nationalizing means of production. The role of state here, therefore, is to regulate. As such, the state is relatively an impartial umpire meditating inter-class and intra-class struggles through harmonization and reconciliation of class interests. The developed capitalist states of the West are, therefore, considered to exemplify this high relative autonomy, and as a result, exhibit high level of human rights observance and protection (Ake, 1976; Alavi, 1972). Conversely, a state exhibits low autonomy when there is low commodification of capital or low penetration of (private) capital into the economy in such a way that the ruling class is constantly engage in primitive accumulation of capital through embezzlement of public fund. The state becomes the only avenue for capital accumulation. The state is thus, interventionist for engaging in productive activities of means of productive activities (i.e. public corporation) by nationalization of major means of production. This state does not limit itself to regulatory rule and is hence compromised, such that instead of rising above class struggle it is deeply immersed in it (Ake, 1981; 1985). The Nigerian state like other developing state exhibits a low level of the autonomy of the state as a result of low commodification of capital. Under the electric mixture of mixed economy, Nigeria experiences the phenomenon of lack of penetration of (private) capital into the economy creating a parasitic petty bourgeois class whose major source of accumulation of capital is the state. Hence, the Nigerian state becomes the only avenue for (primitive) accumulation of capital through which the governing class (i.e. petty bourgeoisie) produce and reproduce their dominance. The implication of the low autonomy of the Nigerian state is that it is immersed in the class struggle rather than rising above it leading to intense struggle for the control of the state for primitive accumulation and marginalization of everything (Ake, 2001). According to Patrick (2007:644-662) the term "failed state" is often used to describe a state perceived as having failed at some of basic conditions and responsibilities of a sovereign government. A failed state is one that has shattered social and political structures. It is characterized by social, political and economic failure. Common characteristics of a failing state is when a central government is so weak or ineffective that it has little practical control over much of its territory, non-provision of public utilities or services, widespread corruption and criminality; refugees and involuntary movement of populations, and sharp economic decline. Thurer (1999) notes that failing states are invariably the product of a collapse of the power structures providing political supports for law and order, a process generally trigged and accompanied by anarchic forms of internal violence. It is the collapse of state institutions, especially the police and judiciary with resulting paralysis of governance, a breakdown of law and order, and general banditry and chaos. Not only are the functions of government suspended, but its assets are destroyed or looted; and experienced officials are killed or flee the country.

According to Thurer (1999:1-5) failed states are:

States in which institutions and law and order have totally or partially collapsed under the pressure and amidst the confusion of erupting violence, yet which subsist as a ghostly presence in the world map. The term "failed state" should be understood to mean disintegrated or collapsed state.

The Fund for Peace propose the following attributes or characteristics of a failed state in order to make it more precise (a) loss of physical control of its territory, or of the monopoly on the legitimate use of physical force (b) erosion of authority to make collective decision (c) an inability to provide reasonable public services and (d) an inability to interact with other states as full member of the international community.Anyanwu (2005) states that by a failed state we mean a state that is unable to meet the needs and aspirations of its masses. A failed state as opposed to capable state is a state which has failed to provide for its citizen such basics needs like adequate security, food, water, electricity, health care, good roads, etc. Nigeria is by all indications or indices a failed state - a state where nothing works. Even those ones that 
work in other countries once adopted in Nigeria refused to work.

\subsection{The Nigerian State and Salw Proliferation in Nigeria}

\subsubsection{History of Proliferation of SALW in Nigeria}

Perhaps, gun possession by civilians in Nigeria is not new and predates colonialism. Guns were introduced by the Europeans prior to colonialism during legitimate and illegitimate (slave) trade between them and Africans. Subsequently, guns and other arms, ammunition and weapons were used by Europeans to realize their imperial ambitions when they used force to suppress Africa's resistance to European incursion, conquest and colonialism. The gunboat diplomacy was popularly employed by the British to compel African chiefs to enter into various treaties with them. There was establishment of West African Frontier Force (WAFF) used by the British which was used to execute the British-Aro War of (1901-1902), and other forms of resistance in Nigeria, West Africa, and Africa. The role of Royal Niger Company (RNC) later United African Company (UAC) backed by British Government in using force to suppress dissenting communities is imperative (Chuma-Okoro, 2011). These arms or guns possibly found their ways to the hands of Africans during the period of colonialism subsequently used in tradition and hunting in the rural community. In no time, guns and gun powder became symbols of strength and power, and were later transformed into ceremonial weapons displayed during funerals, burials, ceremonies and customary festivals among the natives. They also became symbols of individual and ethnic grandeur, and for deterring aggressors and invaders. Today, guns are no longer just ornaments of prestige, or just for hunting, safari and expedition. Guns have transformed in terms of functionality, lethality, sophistication, ubiquity and motive of ownership. They have become more weapons of criminality and instruments of the underworld (ChumaOkoro, 2011). Ostensibly, the 1959 Firearms Act was enacted to check the increasingly rate of arms proliferation in Nigeria towards independence. The failure of the Nigerian government to execute a comprehensive disarmament and arms destruction programme after the civil war (1967-1970) exacerbated the proliferation of guns and illicit arms trafficking. As at 2002, the number of SALW in Nigeria was estimated by various reports and studies at between 1 and 3 million including arms in lawful possession of members of the armed forces and the police and those (majority) in the hands of civilians. The $80 \%$ of SALW in civilian possession were illegally acquired because of the strict regulations. There is fear that a larger percentage of the SALW in circulation in Nigeria are illicit or illegal. Some of these illicit SALW were used in armed violence such as ethnic-religious conflicts, communal clashes, sectarian violence, cultism, political violence, electoral violence, vigilantism, militancy and criminality. Between November 2006 and February 2007, 212 cases of violent crime were reported, 189 of these were carried out with firearms, 34 with other tools and two involved bombs (Chuma-Okoro, 2011). For arms and ammunition possessed by Nigeria Police Force see Table 3.1 below.

Table 3.1: Nigeria Police Force (NPF) Small Arms and Ammunition

\begin{tabular}{|l|c|c|}
\hline \multicolumn{1}{|c|}{ Types of Arms } & $\begin{array}{c}\text { Present } \\
\text { Holdings }\end{array}$ & $\begin{array}{c}\text { Estimated Additional } \\
\text { Requirements over next five years }\end{array}$ \\
\hline $\begin{array}{l}\text { Pistols (various models): Revolver 38mm, revolver chief special shot, Browning } \\
\text { 9mm, revolver 38mm, chief long Browning DA, Browning 32mm, Beretta 9mm. }\end{array}$ & 8,524 & 20,000 \\
\hline $\begin{array}{l}\text { Rifles (various models): K2, FWC, SMG Model 12, SMG Beretta, Sterling, } \\
\text { Beretta pump action shotgun, submachine gun, AK-47. }\end{array}$ & 65,000 & 510,500 \\
\hline Ammunition: & $\begin{array}{c}\text { (Rounds) } \\
650,000\end{array}$ & (Rounds) \\
5.56 mm for rifles & 434,000 & $5,000,000$ \\
9mmfor rifles & & 100,000 \\
\hline
\end{tabular}

Sources: Small Arms Survey, 2007.

\subsubsection{The Nigerian State and Proliferation of SALW in the Northern Nigeria}

Out of an estimated 640 million SALW in circulation world-wide, 100 million are estimated to be Africa, about 30 million in sub-Saharan Africa and 8 million in West Africa alone. It is instructive to mention at this junction that SALW does not just move everywhere, but where they are demanded. Therefore, there are demand factors in the proliferation of SALW. The Nigerian state has made several efforts to check the proliferation of SALW but not from the demand side, or the root causes. Thus, most of these efforts had been superficial or superfluous. For example, the Nigerian government 
established National Commissions for the Control of the Proliferation and Unlawful Circulation of Light Weapons (NATCOM) for the implementation of the ECOWAS moratorium in July 2000 less than two years after the agreement on the moratorium which was politically-binding moratorium on the importation, exportation and manufacture of small arms, later legally binding in 2006. A year later in July 2001, the NATCOM publicly destroyed a stockpile of arms and ammunition seized by the security forces in which a total of 1,257 weapons worth 50 million Naira were destroyed. Among the weapons destroyed were 428 rifles, 494 imported pistols and 287 locally made pistols. These unlawful weapons were seized by the security forces between 1998 and 2001. In September 2001, a request by the NATCOM for the suspension of the granting of licences to carry weapons by police representatives was accepted (Aderinwale, 2005; Ocheche, 2005; Vines, 2005; Stohl and Tuttle, 2009). Nigerian government played a prominent role in the adoption of the Declaration of a Moratorium on Importation, Exportation and Manufacture of Light Weapons in West Africa signed on October 31, 1998 in Abuja, Nigeria renewable for a period of three years later extended in 2001. On December 1999, the ECOWAS member states adopted a code of conduct for implementation of the Moratorium. The Programme for Coordination and Assistance for Security and Development (PCASED) was established with assistance from UNDP (Ndime, 2005). The Nigerian government has also entered into bilateral cooperation with its neighbours, Benin Republic, Niger, Chad and Cameroon. They have taken a number of measures to boost cross-border cooperation and enhance security at the borders. These measures include the establishment of joint commissions like Chad-Nigeria Joint Commission, Niger-Nigeria Joint Commission, Benin-Nigeria Joint Commission, Cameroon-Nigeria Joint Commission, Lake Chad Basin Commission and joint border patrols between Nigeria and Republic of Benin (Adejo, 2005).Nigeria has been an active participant in multilateral arrangements both in terms of regional and global discussions on SALW proliferation. Nigeria is a signatory to a number of international measures to curb SALW proliferation. It supported the adoption in 2005 of the international instrument to Enable States to Identify and Trace Illicit Small Arms and Light Weapons, and has argued that political document needs to be transformed into a legally binding instrument in order to control effectively and criminalize the illicit movement of SALW. Nigeria has as well recommended consideration of sanctions for those found diverting arms into illegal networks, the establishment of common international standard for regulating the activities of arms brokers, integrating SALW measures into comprehensive national development strategies, and establishment of a common standard for end-user certification and stockpile management. At the regional level, Nigeria has supported ECOWAS measures aimed at reducing the proliferation of SALW. At the global level, Nigeria is a signatory to the United Nations (UN) Firearms Protocol on November 13, 2001; which it ratified on July 15, 2004 (Vines, 2005; Adekanye, 2006; Hazen and Horner, 2007). Nigeria supported the extension of ECOWAS Moratorium in October 2004 for the second time and the agreement to strengthen it by transforming it into a legally binding convention. A working draft, titled the "Protocol Regarding the Fight against the Proliferation of Small Arms and Light Weapons, Their Munitions and Other Related Materials" (Vines, 2005). For Nigerian's participation in measures to reduce SALW between 1997 and 2006, see Table 3.2.

Table 3.2: Nigeria's Participation in Measures to Address SALW, 1997-2006

\begin{tabular}{|c|c|}
\hline Years & Instrument \\
\hline 1997 & $\begin{array}{l}\text { Convention on the Proliferation of the Use, Stockpiling, Production and Transfer of Anti-Personnel } \\
\text { Mines and on Their Destruction (entered into force in 1999). }\end{array}$ \\
\hline 1998 & $\begin{array}{l}\text { Economic Community of West African States (ECOWAS) Moratorium on the Importation, Exportation } \\
\text { and Manufacture of Light Weapons (ECOWAS Moratorium) reviewed in } 2001 \text { and 2004) }\end{array}$ \\
\hline 2000 & $\begin{array}{l}\text { Bamako Declaration on an African Common Position on the Illicit Proliferation, Circulation and } \\
\text { Trafficking of Small Arms and Light Weapons. }\end{array}$ \\
\hline 2000 & United Nations Convention Against Transnational Organized Crime (entered into force in 2003). \\
\hline 2001 & $\begin{array}{l}\text { United Nations (UN) Programme of Action to Prevent, Combat and Eradicate the Illicit Trade in Small } \\
\text { Arms and Light Weapons in All its Aspects (Programme of Action). }\end{array}$ \\
\hline 2001 & $\begin{array}{l}\text { Protocol Against the Illicit Manufacturing of and Trafficking in Firearms, Their Parts and Components } \\
\text { and Ammunition (entered into force in 2005). }\end{array}$ \\
\hline 2005 & International Instrument to Enable States to Identify and Trace Illicit Small Arms and Light Weapons. \\
\hline 2006 & $\begin{array}{l}\text { ECOWAS Convention on Small Arms and Light Weapons, Their Ammunition and Other Related } \\
\text { Materials (ECOWAS Convention, yet enter into force as of 2006) }\end{array}$ \\
\hline
\end{tabular}

Source: Culled from Hazen and Horner (2007). 
At the national level, Nigeria continues to rely on the National Firearms Act of 1959 as the legal instrument governing small arms possession, manufacture and the use in the country as amended even though the Robbery and Firearms (Special Provisions) Decree No.5 was promulgated in 1984 and later the Robbery and Firearms (Special Provisions) Act. Proposals were made that the laws be revised and up dated following the UN Programme of Action in 2001, but to date there have been no efforts to overhaul the national legislation on small arms. President Obasanjo initiated a number of committees aimed at addressing the issues of proliferation, disarmament and related matters, but to date these committees have made little progress in tackling these issues (Hazen and Horner , 2007; Chuma-Okoro, 2011). In July 2000, the Nigerian government established a National Committee on the Proliferation and Illicit Trafficking in Small Arms and Light Weapons the purpose of which was to determine the sourcing illegal small arms and collect information on small arms proliferation in Nigeria. In May 2001, the government established a second committee aimed at implementing the 1998 ECOWAS Moratorium. These two committees were later merged into a single committee. The committee has accomplished very little in the past five years in large part due to lack of political will, financial support, technical expertise, and institutional capacity. In other words, NATCOM was incapacitated by underfunding, corruption on the part of law enforcement agencies, etc. Rather than being established as an independent commission the committee has been placed under the Ministry of Foreign Affairs. Staffing of the Committee is not permanent rather individuals with full-time appointments are asked to serve in the Committee. The Committee produced an ambitions works plan in 2003, but unable to implement these activities. Originally conceived of as a primary documentation centre on small arms and light weapons, the Committee has not yet demonstrated capacity to perform this role (Hazen and Horner 2007; Chuma-Okoro, 2011). There were renewed efforts in 2007 to revive the activities of the Committee and legislation is being written to convert the Committee into a national commission. The Committee is currently preparing to conduct a national survey of small arms by the end of 2007. It is seeking support from the ECOWAS Small Arms Programme to conduct the survey and to undertake other activities in support of the implementation of the 2006 ECOWAS Convention (Hazen and Horner, 2007). Inaugurated in 2001, the NATCOM is responsible for the registration and control of SALW, and granting of permits for exemptions under the ECOWAS Moratorium (Chuma-Okoro, 2011). Despite these national-efforts, the rate of accumulation of SALW is increasing and becoming endemic as various forms of violence and casualties are in the recent times recorded in the Northern part of Nigeria. Thus, the proliferation of SALW in Nigeria has a destabilizing effect. There is lack of capacity and strong legal or effective institutional frameworks to regulate SALW and combat the phenomenon of SALW proliferation in Nigeria, particularly Northern part of Nigeria (Chuma-Okoro, 2011). More fundamentally, the Nigerian state is yet to deal with the demand factors of SALW proliferation preferring to dwell on the symptoms rather than the root causes. The demand factors are the root causes of SALW proliferation, because if there is no demand there will be no supply. Nigeria is the source, transit and destination of SALW, and therefore the demand factors include mass unemployment, poverty, corruption, excessive militarization, failure of political leadership, misgovernance, bad leadership, poor governance, state violence, among others. There is indeed excess politicization, state-sponsored violence and state proliferation of SALW leading to political violence, electoral violence and other forms of violence. For example, virtually all the law enforcement or security agencies are allowed to carry arms with exemption of few that are even lobbying to be allowed to carry weapons, thus militarizing the society more. In fact, the Nigerian state was not been able to deal with these demand factors, because dealing with it means dealing with itself or starting by reforming itself. The political class in their struggle or contest for political power has sacrificed everything in the name of politics including suppressing class consciousness and promoting ethno-religious consciousness. The promotion of ethnic and religious consciousness at the expense of class consciousness has resulted to the increasing demand of SALW for executing ethno-religious violence, election and political violence, communal wars, sectarian violence, etc. The unemployed and ignorant youths have been a willing tool in this intense struggle for state power. No doubt colonialism and many years of military rule contributed to the excessive militarization of the Nigerian society and intensive political contest for the soul of the Nigerian state resulting to the rising demand factors for SALW. So it is actually a product and a combination of many years of political leadership failure tilting the Nigerian state towards the status of a failed state. A state that is not able to deal with matters or issues of political corruption, poverty, mass unemployment and economic hardship leading to increasing demand for SALW (Okafor, Okeke and Aniche, 2012). Thus, we conclude that the inability of the Nigerian state to deal with the demand factors of SALW heightens proliferation of small arms and light weapons (SALW) in Nigeria, particularly the northern part of the country. As an indication of this militarization of the Nigerian society, the oil companies are allowed to operate private security outfits. Private security outfits, bodyguards, vigilante and thugs have proliferated over the years (Nte, 2011). One stimulant for the proliferation of SALW in Nigeria is elections such that in 2003 elections, locally fabricated and imported pistols, and a range of assault riffles were used by political thugs. In one of the states in Nigeria, Cross River State, the police recovered 54 guns in 2002, 16 in possession of politicians and 
another eight from politically motivated murders. In Edo State a gubernatorial aspirant by name Lucky Imasuen was arrested in possession of arms. In Bayelsa State, eleven people were killed in shootout by politicians contesting councillorship elections. In Ondo State, police confirmed that a politician was stockpiling light weapons and found 13 single-barrel guns in his residence. In August 2003, the police arrested the son of a prominent senator whom the police believed to have been behind the importation of sophisticated arms used by armed robbers and feuding ethnic groups. The police themselves are frequently involved in what is called "gunpowder politics". In 2003, a governor encouraged the production of pistols by a gang for a political campaign. Also, in 2003 elections political agents visited a number of university campuses and recruited students into their thugs arming them with various weapons (Vines, 2005).

\section{SALW Proliferation and Security Situations in the Northern Nigeria}

\subsection{The Supply Factors and Causes of Proliferation of SALW}

There are demand and the supply factors or pull and push factors of proliferation of SALW. We mentioned the demand factors in the preceding chapters and here we shall focus on supply factors. The supply or push factors are those causes of SALW proliferation that have to do with the sources and transits of SALW or arms trafficking. As we noted earlier, Nigeria is origin, transit and destination of arms trafficking which means Nigeria manufactures, imports and exports SALW. Most of the studies had concentrated on importation of SALW or cross-border trafficking or smuggling of arms downplaying the local manufacture and supply of SALW. In this chapter, we shall discuss the causes, sources, local source and arms theft in Nigeria. For example, more than 1,135 companies, in more than 98 countries are involved in some aspects of production of small arms, ammunition and or components. At least 60 of them are involved in legal export of small arms. In the last 40 years, the number of countries producing small arms had doubled, and the majority of these small arms producing companies are located in West European countries. By 2004, all West European countries hosted companies producing small arms or their components which are dominated by the Belgian company FN Herstal and the German Hecker and Kock. Other small arms producing companies include the Italian Beretta, and Austrian Steyr Mannliher and French GIAT and Spanish Santa Barbara Sistemas. The Belgian FN Herstal is the largest SALW manufacturing company in Western Europe with a total sale valued approximately at EUR 400 million in 2003. Its most popular product, FAL assault riffles are in service in many countries, and almost 100 percent of Herstal Group sales are derived from sales outside Belgium (Nte, 2011). The exact origins and transit countries of the illicit small arms and ammunition flows into Nigeria are from Cote d'Ivoire, Liberia, South Africa, Turkey, Ukraine, Bulgaria, Kosovo Serbia, Equatorial Guinea, Gabon, Cameroon and within Nigeria itself. For example, in 2011 a ship load of arms and ammunition was discovered in the Nigerian port, and the Iranian arms agent arrested. This shows that guns are also produced locally by illegal craft gunsmith. For example, in June 2007, it was reported that the police confiscated 40 pistols from a local blacksmith in Niger State (Nte, 2011). Also a blacksmith in Plateau State who in 2004 with the help of Nigerian politician traveled to Ghana to receive training on gun manufacturing for pistols and shotguns is one of these local sources of small arms (Vines, 2005). Harzen and Horner (2007) have noted that given the difficulty in legally owing a gun which makes it difficult to track flows and possession. SALW are imported into Nigeria across land and sea borders. Sources of small arms include arms dealers, serving and retired military and police officers, returning peacekeepers, armed groups across borders, and other individuals. There are also local craft producers such as in Awka see Table 4.1.

Table 4.1: Craft-Producing Small Arms in Awka

\begin{tabular}{|c|l|c|c|}
\hline Weapon & \multicolumn{1}{|c|}{ Features } & Ammunition & cost \\
\hline $\begin{array}{c}\text { Pocket single-shot } \\
\text { gun }\end{array}$ & $\begin{array}{l}\text { Approximately 13cm long, steel muzzle to wooden stock, } \\
\text { extremely rudimentary hammer requiring cocking, effective } \\
\text { only at a distance of 1-2m, uses single shotgun cartridge. }\end{array}$ & $\begin{array}{c}\text { Various calibres } \\
\text { shotgun cartridge }\end{array}$ & $\mathrm{N} 4000 / \$ 32$ \\
\hline Four-shot revolver & Available in manual and automatic configurations. & $9 \mathrm{~mm}, 7.5 \mathrm{~mm}$ or $8.5 \mathrm{~mm}$ & $\mathrm{~N} 8000 / \$ 64$ \\
\hline Eight-shot revolver & Available in manual and automatic configurations & $9 \mathrm{~mm}, 7.5 \mathrm{~mm}$ or $8.5 \mathrm{~mm}$ & $\mathrm{~N} 12,000 / \$ 96$ \\
\hline Single barrel shotgun & Breech-loading, safety cocking mechanism & $\begin{array}{c}\text { Various calibres of } \\
\text { shotgun cartridge }\end{array}$ & $\begin{array}{c}\mathrm{N} 10,000- \\
\mathrm{N} 11,000 / \$ 80-\$ 88\end{array}$ \\
\hline $\begin{array}{c}\text { Horizontal double- } \\
\text { barrel shotgun }\end{array}$ & $\begin{array}{l}\text { Breech-loading, one trigger for each barrel, safety cocking } \\
\text { mechanism }\end{array}$ & $\begin{array}{c}\text { Various calibres of } \\
\text { shotgun cartridge }\end{array}$ & $\begin{array}{c}\mathrm{N} 25,000- \\
\mathrm{N} 30,000 / \$ 200- \\
\$ 240\end{array}$ \\
\hline $\begin{array}{c}\text { Vertical double barrel } \\
\text { shotgun }\end{array}$ & $\begin{array}{l}\text { Automatic configuration firing both rounds without need for } \\
\text { cocking breech-loading }\end{array}$ & $\begin{array}{c}\text { Various calibres of } \\
\text { shotgun cartridges }\end{array}$ & $\mathrm{N} 45,000 / \$ 360$ \\
\hline
\end{tabular}


Source: Hazen and Horner (2007).

Other local craft small arms are located in Katsina, Kaduna and Calabar, and recently in Borno and Yobe States with the Boko Haram locally producing bombs (Hazen and Horner, 2007). Therefore, sources of illicit and illegal SALW in Nigeria include cross border smuggling, security sector black marketeering and rentals, local manufacturing, organized crime and gun-running, air transportation agent, land transportation agent, arms broker and blacksmith (Vines, 2005; ChumaOkoro, 2011). The causes of proliferation of SALW or arms trafficking in Nigeria include trafficking in small arms, local arms production, arms theft, etc. Some of the factors that contribute to proliferation of SALW include poverty, economic disparity, police presence, ethno-religious diversity, the quest for easy profits, self-defence reflex, rise in crime, cultural practices, greed, porous borders, inadequate border protection, etc. The motivations for SALW possession and proliferation include military activities, multiplicity of conflicts and personal security arrangement, insecurity, privatization of security, etc (John, Mohammed, Pinto and Nkanta, 2007; Hazen and Horner, 2007; Chuma-Okoro, 2011).

\subsection{The Law Enforcement Agencies, SALW Proliferation and Security Situations in the Northern Nigeria}

The main enforcement agencies responsible for checking arms trafficking and proliferation of SALW in Nigeria are the Nigeria Police Force, the custom service, the immigration service, among others. The law enforcement agencies have made various efforts at checkmating SALW trafficking and proliferation. For information on seizures of illegal arms trafficking by the Nigerian customs, Nigeria Police Force and others see Tables 4.2, 4.3 and 4.4 below.

Table 4.2: Nigeria Customs Service Seizure, 1999-2006

\begin{tabular}{|c|c|c|c|c|}
\hline Year & Date & Number of Arms seized & Number of rounds of Ammunition/Cartridges seized & Location \\
\hline $\begin{array}{l}1999 \\
2000\end{array}$ & $\begin{array}{l}\text { February } 5 \\
\text { July } 20 \\
\text { July } 23 \\
\text { n.d }\end{array}$ & $\begin{array}{l}1 \\
0 \\
1 \\
0\end{array}$ & $\begin{array}{c}1,200 \\
2,900 \\
0 \\
1,075\end{array}$ & \begin{tabular}{|l|} 
Lagos \\
Lagos \\
Port Harcourt \\
Lagos \\
\end{tabular} \\
\hline 2001 & \begin{tabular}{|l|} 
April 27 \\
February 10 \\
June 12
\end{tabular} & $\begin{array}{l}2 \\
0 \\
0\end{array}$ & $\begin{array}{c}0 \\
1,290 \\
1,712 \\
\end{array}$ & $\begin{array}{l}\text { Abuja } \\
\text { Seme/Badagry } \\
\text { Seme/Badagry }\end{array}$ \\
\hline 2002 & December 15 n.d & $\begin{array}{l}0 \\
2 \\
\end{array}$ & $\begin{array}{c}5,924 \\
20 \\
\end{array}$ & $\begin{array}{l}\text { Seme/Badagry } \\
\text { Lagos }\end{array}$ \\
\hline 2003 & \begin{tabular}{|l} 
April 21 \\
January 15 \\
January 22 \\
February 7 \\
April 1 \\
n.d \\
January 22 \\
February 11 \\
June 23 \\
November 9 \\
November 23 \\
November 24 \\
\end{tabular} & $\begin{array}{l}1 \\
8 \\
0 \\
4 \\
1 \\
0 \\
0 \\
0 \\
0 \\
0 \\
0 \\
0\end{array}$ & $\begin{array}{c}6 \\
0 \\
1,250 \\
15,000 \\
0 \\
250 \\
15,000 \\
10,000 \\
102,000 \\
170,000 \\
1,875 \\
38,000 \\
\end{array}$ & \begin{tabular}{|l|} 
Lagos \\
Lagos \\
Minna, Niger State \\
Seme/Badagry \\
Port Harcourt \\
Seme/Badagry \\
Seme/Badagry \\
Seme/Badagry \\
Seme/Badagry \\
Ogele-Shagamu \\
Lokki-Ajalah beach \\
ljebu.Ode waterside
\end{tabular} \\
\hline 2004 & \begin{tabular}{|l|} 
February 16 \\
May 21 \\
May 8 \\
\end{tabular} & $\begin{array}{l}1 \\
9 \\
1 \\
\end{array}$ & $\begin{array}{c}500 \\
0 \\
0\end{array}$ & $\begin{array}{l}\text { Gwagwalada (FCT) } \\
\text { Lagos } \\
\text { Idiroko }\end{array}$ \\
\hline 2005 & \begin{tabular}{|l|} 
January 13 \\
April 18 \\
June 28 \\
August 1 \\
August 1
\end{tabular} & $\begin{array}{l}1 \\
0 \\
0 \\
1 \\
0\end{array}$ & $\begin{array}{c}0 \\
216 \\
32,510 \\
6,740 \\
500\end{array}$ & \begin{tabular}{|l|} 
Borno \\
Lagos \\
Abuja \\
Osun/Oyo \\
Jos (Plateau Sate)
\end{tabular} \\
\hline 2006 & January 23 & 0 & 750 & Owerri \\
\hline
\end{tabular}

Source: Nigeria Customs Service, Enforcement and Drug Statistics Section, Abuja culled from Hazen and Horner (2007). 
Table 4.3: Small Arms Seized by Nigeria Police 2000-2003

\begin{tabular}{|c|c|}
\hline Year & Number of Arms Seized \\
\hline $2000-2001$ & 1,941 \\
2002 & 3,150 \\
2003 & 3,451 \\
\hline
\end{tabular}

Source: Dambatta (2004) cited in Hazen and Horner (2007).

Table 4.4: Arms Seizure Information, 2002-2007

\begin{tabular}{|c|c|c|c|}
\hline Year & Date & Number of Arms Seized & Number of Rounds of Ammunition/Cartridge Seized \\
\hline \multirow{4}{*}{2002} & February 2 & 0 & 5,924 \\
\hline & June 24 & 0 & 102,000 \\
\hline & July 14 & 2 & 15 \\
\hline & July 19 & 13 & 189 \\
\hline \multirow{3}{*}{2003} & January 22 & 0 & 15,000 \\
\hline & November 17 & 0 & 170,000 \\
\hline & November 27 & 0 & 38,000 \\
\hline \multirow{2}{*}{2004} & January 25 & 16 & 1,527 \\
\hline & September 1 & 0 & 75 \\
\hline \multirow{2}{*}{2005} & May 21 & 0 & 1,094 \\
\hline & December 19 & 3 & 0 \\
\hline \multirow{4}{*}{2006} & March 17 & 5 & 580 \\
\hline & April 29 & "Weapons" & 0 \\
\hline & October 11 & 51 & 0 \\
\hline & October 27 & 5 & 105 \\
\hline \multirow{4}{*}{2007} & February 13 & & "Ammunition" \\
\hline & February 14 & 7 trailers of arms "weapons" & 0 \\
\hline & March 19 & 21 & 0 \\
\hline & $\begin{array}{l}\text { March } 31 \\
\text { April } 10\end{array}$ & 2 & $\begin{array}{c}17 \\
\text { "Several rounds" }\end{array}$ \\
\hline
\end{tabular}

Source: Adopted from Vanguard, This Day and AllAfrica.com cited in Hazen and Horner (2007).

Despite these seizures illicit proliferation and illegal arms trafficking are on the increase in Nigeria. Hazen and Horner (2007) noted that there is limited capacity of the security forces. The problems of armed violence and small arms proliferation are worsened by the inability of the police to reduce violent crime, ensure law and order, and provide security to the populace. None of the security forces currently possesses the training, resources, or personnel to perform effectively. The lengthy and porous nature of the borders contributes to logistic problems. Poor police capacity has led to the development of a security gap, which explains the use of vigilante. The use of vigilante in turn worsens the SALW proliferation. In addition to porous nature of Nigerian borders, the heterogeneous nature of the border communities is another source of problems. For example, between 1964 and 1994, over a period of 30 years, Nigeria recorded over 30 border incidents with Cameroon. It is clear that Nigeria's borders are too expensive to be effectively policed by the law enforcement agents. The country's maritime borders cannot be effectively covered or monitored by the Nigerian navy. Similarly, the combined efforts of the Army, the Police, the Customs and the Immigration Service cannot effectively control the extensive land borders. In Borno State, for instance, because of the porous nature of the border with Cameroon, the border may be crossed at any point by various means of transport during dry season. West African border control is poor or inadequate because of lack of technical infrastructure and human resources. The dilapidation of border control points is compounded by the dispiritedness of the security services personnel. Generally speaking, West African boundaries are very tortuous, for example, some borders fallow a river bank or the bottom of a valley. West African borders are extremely long and as a result surveillance is costly and access to the borders is difficult due to sparseness of road network (Adejo, 2005; Fall, 2005; Hazen and Horner, 2007).

Thus, our conclusion is that the inability of the law enforcement agencies to check the supply factors of SALW worsens security situations in the Northern part of Nigeria. 


\section{Summary, Conclusions and Recommendations}

\subsection{The Summary}

We started by dwelling on all the technically in the chapter one, where we posed four research questions, stated four specific objectives, and four research hypotheses. We, also, demonstrated the theoretical and empirical relevance or justifications of this study. The issues, time frame and subjects covered by the study were also highlighted. The main concepts or terms used in this study were operationalized or defined as they are applied or used in this study.

In the chapter two, we reviewed the related extent and relevant literature concerning causes, sources, transits and destinations of SALW and problems and consequences of SALW in Nigeria. In Chapter Three, we discussed the history of proliferation of SALW in Nigeria, and the Nigerian state and proliferation of SALW in the Northern Nigeria.

Whilst, in Chapter Four we examined the supply factors and causes of proliferation of SALW, and the law enforcement agencies, SALW proliferation and security situations in the Northern Nigeria. Lastly, in Chapter Five, we summarized the entire work and drew some conclusions on the basis of which we made some recommendations.

\subsection{Conclusions}

From the foregoing, we reached the following conclusions:

That the inability of the Nigerian state to deal with the demand factors heightened the proliferation of SALW in the Northern part of Nigeria.

That the inability of the law enforcement agencies to check the supply factors of SALW worsened security situations in the Northern part of Nigeria.

\subsection{Recommendations}

In the course of this study, we suggest the following recommendations:

Reconstitute the Nigerian state in such a way as to be proactive in dealing with the demand factors of SALW that heightens the proliferation of SALW.

Strengthen the law enforcement agencies in order to enable them check the supply factors of SALW that worsens security situations in the Northern part of Nigeria.

\section{Refereces}

\section{Books}

Abcarian, G. and Masannat, G. (1970) Contemporary Political System, New York: Charles Scribner's sons.

Adejo, P.Y. (2005) "Crime and Cross-Border Movement of Weapons: The Case of Nigeria" in A. Ayissi and I, Sall (eds), Combating the Proliferation of Small Arms and Light Weapons in West Africa: Handbook for the Training of Armed and Security Forces, Geneva: United Nations Institute of Disarmament Research (UNIDIR).

Aderinwale, A. (2005) "Civil Society and the Fight against the Proliferation of Small Arms and Light Weapons" Combating the Proliferation of Small Arms and Light Weapons in West Africa: Handbook for the Training of Armed and Security Forces, Geneva: United Nations Institute of Disarmament Research (UNIDIR).

Ake, C. (1981) A Political Economy of Africa, London: Longman Group.

Ake, C. (1985) Political Economy of Nigeria, London: Longman Group.

Ake, C. (2001) Democracy and Development in Africa, Ibadan:

Spectrum Books.

Aniche, E. T. (2006) Substance of Ecumenics and Related Issues, Onitsha: Stageview.

Anikpo, M. (1986) Foundations of Social Science Research: AMethodological Guide for Students, Enugu: ABIC Publishers.

Anyanwu, A. (2002) Research Methodology in Business and Social Science, Owerri: Canun Publishers.

Asika, N. (1999) Research Methodology in the Behavioural Science, Ibadan: Longman Publishers.

Ayissi, A. and Sall, I. (eds) (2005) Combating the Proliferation of Small Arms and Light Weapons in West Africa: Handbook for the Training of Armed and Security Forces, Geneva: United Nations Institute of Disarmament Research (UNIDIR).

Chuma-Okoro, H. (2011) "Proliferation of Small Arms and Light Weapons in Nigeria: Legal Implications" in Law and Security in Nigeria.

Cohen, L. \& Manion, L. (1980) Research Methods in Education,London: Croom Helm.

Cornwal, A. et al. (1994) "Acknowledging Process: Methodological Challenges for Agricultural Research and Extension" in I. Scones \& J. Thompson (eds) Beyond Farmer First, London: Intermediate Technology Publications. 
Fall, H. (2005) "Border Controls and Cross Borders Crime in West Africa" in A. Ayissi and I. Sall (eds) Combating the Proliferation of Small Arms and Light Weapons in West Africa: Handbook for the Training of Armed and Security Forces, Geneva: United Nations Institute of Disarmament Research (UNIDIR).

Florquin, N. and Berman, E. G. (eds) (2005) Armed and Aimless: Armed Groups, Guns, and Human Security in the ECOWAS Regions, Geneva: Small Arms Survey Publication.

Ibrahim, M. (2003) Democracy and the Menace of small Arms of Small Arms proliferation in Nigeria, Lagos: Centre for Democracy and Development.

Isaak, A. (1969) Scope and Methods of Political Science, Homewood:Dorsey Press.

Leege, D. \& Francis, W. (1974) Political Research: Design, Measurement and Analysis, New York: Basic Book Publishers.

Lundberg, G.A. (1951) Social Research: A study in Method of Gathering Data, New York: Longman.

Marx, K. and Engels, F. (1977) Manifesto of the Communist Party, Moscow: Progress Publishers.

Ndime, D. (2005) "Corporation between States to Combat the Proliferation of Small Arms and Light Weapons" in A. Ayissi and I. Sall (eds) Combating the Proliferation of Small Arms and Light Weapons in West Africa: Handbook for the Training of Armed and Security Forces, Geneva: United Nations Institute of Disarmament Research (UNIDIR).

Nkpa, N. (1997) Educational Research for Modern Scholars, Enugu: Fourth Dimension Publishers.

Nwana, O.C. (1981) Introduction to Education Research, Ibadan: University Press Ltd.

Ocheche, S. (2005) "Cooperating with Civilians and the Security Forces in Efforts to Combat the Proliferation of Small Arms and Light Weapons" in A. Ayissi and I. Sall (eds) Combating the Proliferation of Small Arms and Light Weapons in West Africa: Handbook for the Training of Armed and Security Forces, Geneva: United Nations Institute of Disarmament Research (UNIDIR).

Obasi, I. N. (1999) Research Methodology in Political Science, Enugu: Academic Publishing Company.

Offordile, C. (2002) Introduction to Research and Methodology, Enugu: Snaap Press.

Ogoamaka, P.M.C (2002) Towards Uniformity in Research, Owerri:Cape Publishers.

Sall, A. (2005) "Techniques for Combating Arms Proliferation in West Africa: Legal Aspects" in A. Ayissi and I. Sall (eds) Combating the Proliferation of Small Arms and Light Weapons in West Africa: Handbook for the Training of Armed and Security Forces, Geneva: United Nations Institute of Disarmament Research (UNIDIR).

Tuckman, B.W. (1972) Conducting Educational Research, New York: Harcourt Brace Jovanovich Inc.

Vines, A. (2005) "Combating Light Weapons Proliferation in West Africa".

White, I. \& Clark, R. (1976) Political Analysis: Technique and Practice, Pacific Groove: Cole Publishing Company.

\section{Journals}

Ake, C. (1976) "Explanatory Notes on the Political Economy of Africa" Journals of Modern African Studies, 14 (1).

Alavi, H. (1972) "The Post-Colonial State", New Left Review, 74.

Anyanwu, U. (2005) "Failed States in Africa: The Nigerian Case since

1960" American Journal of International Politics and Development Studies (AJIPDS) Vol.1, No. 1.

Hazen, J. M. and Horner, J. (2007) "Small Arms, Armed Violence, and Insecurity in Nigeria: The Niger Delta in Perspective" The Small Arms Survey Occasional Paper 20.

John, I.A., Mohammed, A.Z., Pinto, A.D. and Nkanta, C.A. (2007) "Gun Violence in Nigeria: A Focus on Ethno-Religious Conflict in Kano" Journal of Public Health Policy 28: 420-431.

Nte, N.D. (2011) "The Changing Patterns of Small and Light Weapons (SALW) Proliferation and the Challenges of National Security in Nigeria", Global Journal of Africa Studies 1 (1): 5-23.

Okafor, J.C., Okeke, V.O.S. and Aniche, E.T. (2012) "Power Struggles, Political Contest and Ethno-Religious Violence in Nigeria" Nnamdi Azikiwe Journal of Political Science (Forthcoming). 